\title{
Review on Carbon Dioxide Utilization for Cycloaddition of Epoxides by Ionic Liquid-Modified Hybrid Catalysts: Effect of Influential Parameters and Mechanisms Insight
}

\author{
Jimmy Nelson Appaturi ${ }^{1, *}$, Rajabathar. Jothi Ramalingam ${ }^{2}$, Muthu Kumaran Gnanamani ${ }^{3}$, \\ Govindasami Periyasami ${ }^{2, *} \mathbb{D}$, Prabhakarn Arunachalam ${ }^{2} \mathbb{D}$, Rohana Adnan ${ }^{1}$, Farook Adam ${ }^{1}$, \\ Mohammed D. Wasmiah ${ }^{2}$ and Hamad A. Al-Lohedan ${ }^{2,4}$ \\ 1 School of Chemical Sciences, University Sains Malaysia (USM), Penang 11800, Malaysia; \\ r_adnan@usm.mu (R.A.); farook@usm.my (F.A.) \\ 2 Chemistry Department, College of Science, King Saud University, Riyadh 11451, Saudi Arabia; \\ parunachalam@ksu.edu.sa (P.A.); jot99ram@rediffmail.com (M.D.W.); hlohedan@ksu.edu.sa (H.A.A.-L.) \\ 3 Center for Applied Energy Research, University of Kentucky, 2540 Research Park Drive, \\ Lexington, KY 40511, USA; muthu.gnanamani@uky.edu \\ 4 Surfactant Research Chair, Chemistry Department, College of Science, King Saud University, \\ Riyadh 11451, Saudi Arabia \\ * Correspondence: jimmynelson@usm.my (J.N.A.); jrajabathar@ksu.edu.sa (R.J.R.); \\ pkandhan@ksu.edu.sa (G.P.)
}

check for

updates

Citation: Appaturi, J.N.; Ramalingam, R.J.; Gnanamani, M.K.; Periyasami, G.; Arunachalam, P.; Adnan, R.; Adam, F.; Wasmiah, M.D.; Al-Lohedan, H.A. Review on Carbon Dioxide Utilization for Cycloaddition of Epoxides by Ionic Liquid-Modified Hybrid Catalysts: Effect of Influential Parameters and Mechanisms Insight. Catalysts 2021, 11, 4. https://dx.doi.org/ 10.3390/catal11010004

Received: 17 November 2020 Accepted: 16 December 2020 Published: 23 December 2020

Publisher's Note: MDPI stays neutral with regard to jurisdictional claims in published maps and institutional affiliations.

Copyright: (C) 2020 by the authors. Licensee MDPI, Basel, Switzerland. This article is an open access article distributed under the terms and conditions of the Creative Commons Attribution (CC BY) license (https: / / creativecommons.org/ licenses/by/4.0/).

\begin{abstract}
The storage, utilization, and control of the greenhouse $\left(\mathrm{CO}_{2}\right)$ gas is a topic of interest for researchers in academia and society. The present review article is dedicating to cover the overall role of ionic liquid-modified hybrid materials in cycloaddition reactions. Special emphasis is on the synthesis of various cyclic carbonate using ionic liquid-based modified catalysts. Catalytic activity studies have discussed with respect to process conditions and their effects on conversion and product selectivity for the reaction of cycloaddition of $\mathrm{CO}_{2}$ with styrene oxide. The reaction temperature and the partial pressure of $\mathrm{CO}_{2}$ have found to play a key role in cyclic carbonate formation. The role of other influential parameter (solvent effect) is also discussed for the conversion of cyclic/aromatic oxides to polycarbonate production. Our own research work that deals with ionic liquid-based halide-modified mesoporous catalyst (MCM-41 type) derived from rice husk waste has also been discussed. Finally, the role of carbon dioxide activation and ring-opening mechanisms involved in the cyclic carbonate product formation from $\mathrm{CO}_{2}$ have been discussed.
\end{abstract}

Keywords: greenhouse gas; ionic liquid; mesoporous silica; cycloaddition; poly-carbonate

\section{Introduction}

Greenhouse gas (carbon dioxide- $-\mathrm{CO}_{2}$ ) in the atmosphere helps living things naturally by involving in photosynthesis [1]. About $32 \%$ of $\mathrm{CO}_{2}$ is being produced by hydrocarbon combustion and gasification process that raises concern over environmental pollution [2,3]. The transportation sector contributes nearly 30\% to total carbon dioxide emissions [4]. Figure 1 shows the carbon cycle, $\mathrm{CO}_{2}$ storage, recycle and purification, and utilization mainly of fine chemicals formation by catalysis route. Figure 1 shows the global atmospheric $\mathrm{CO}_{2}$ concentration for about half a decade from 1958 with respect to continuous research reports carried by the Mauna Loa Observatory in Hawaii [3]. The concentration of atmospheric $\mathrm{CO}_{2}$ was 399.89 ppm till May 2013, and in 2020, it reached up to 412.78 ppm [5]. The continuous rise in greenhouse gas $\left(\mathrm{CO}_{2}\right)$ concentration creates global warming issues and continues damage to the green environment. In recent years, smart technologies are developed to store and utilize $\mathrm{CO}_{2}$ reduction and which makes the pollution free atmosphere [6-8]. 




Figure 1. Schematic of carbon cycle for $\mathrm{CO}_{2}$, recycle Storage and greenhouse gas utilization for possible fine chemicals production.

Carbon dioxide is recognized as a nonflammable [9], nontoxic [10], and inexpensive gas [11]. It is a renewable carbon source [12] and thermodynamically stable compound $[13,14]$. Interestingly, carbon oxide can replace the following toxic chemical compounds such as carbonyl dichloride known as phosgene $\left(\mathrm{COCl}_{2}\right)$, carbon monoxide $(\mathrm{CO})$, and isocyanides (R-NCO) for fine chemical applications. Carbon dioxide can be utilized as a mild oxygen source [15]. It can be used as an alternate medium or solvent [16], also work as a supercritical fluid (sc) [17], and act as a carbon source. It can be used based on its unique chemical properties to be incorporated with high "atom efficiency" such as in carboxylation synthesis or in catalyst synthesis [16]. Hutchings $[15,17]$ used supercritical $\mathrm{CO}_{2}$ as an antisolvent for the preparation of $\mathrm{Au} / \mathrm{scCO}_{2}$ and sc-VPO (vanadium phosphate) catalysts. Currently, $\mathrm{CO}_{2}$ has been used in various industrial applications such as chemical, pharmaceutical, foodstuff, laboratories and analysis, beverage, and pulp and paper industries [16]. The application of $\mathrm{CO}_{2}$ as $\mathrm{C} 1$ raw material in the chemical industry was started in past few decades. It has been reported that approximately 110 million metric tons of $\mathrm{CO}_{2}$ are currently used every year in the chemical industry. In the present decade, carbon dioxide utilization has reached around 110 million MT (metric tons) [18]. Carbon dioxide is also playing major role in the production of urea, [17] methanol [18], salicylic-acid [19], formic-acid [20], cyclic carbonates [21-23], copolymers, polymer building blocks, and fine chemicals [24-27]. Urea is one of the major fertilizers, and $\mathrm{CO}_{2}$ is the source for it [26]. The urea is prepared from ammonia and $\mathrm{CO}_{2}$ in fertilizer [28] and also in fabrication process of various types of polymers, such as melamine and urea-formaldehyde resin [29-32]. Salicylic acid is produced from phenol and $\mathrm{CO}_{2}$ via the Kolbe-Schmitt reaction [33]. The product is used to produce acetyl salicylic acid which is also known as aspirin, used mostly in healthcare applications [34-36]. Everyday monitoring of Carbon dioxide emission in atmosphere have shown in online website (www.co2.earth) to monitor the Keeling Curve of Atmospheric $\mathrm{CO}_{2}$ concentration emission between 1958 to 16 August 2020 [5,35].

The cyclic carbonates are odorless, colorless, and biodegradable [37,38]. The cyclic carbonates are used in industries as aprotic polar solvents [39], as a monomer for polymer synthesis, and as additives [40]. Besides, it is also been used in electrolytic materials such as secondary batteries (lithium batteries) [41], cosmetics, resins, and cleaning utensils [42]. Cyclic carbonates are utilized as an intermediate compound in the biomedical and pharma industries [12]. Cyclic carbonates also play a key role in herbicides and disinfectants synthesis [43] as well as are fuel additives [44].

Traditionally, phosgene with ethane-1,2-diol in dichloromethane solvent was utilized to produce cyclic carbonates, and one of the products is hydrochloric acid obtained as a 
by-product, which is harmful to human beings [43]. Scheme 1 shows the conventional synthesis of organic cyclic carbonates.

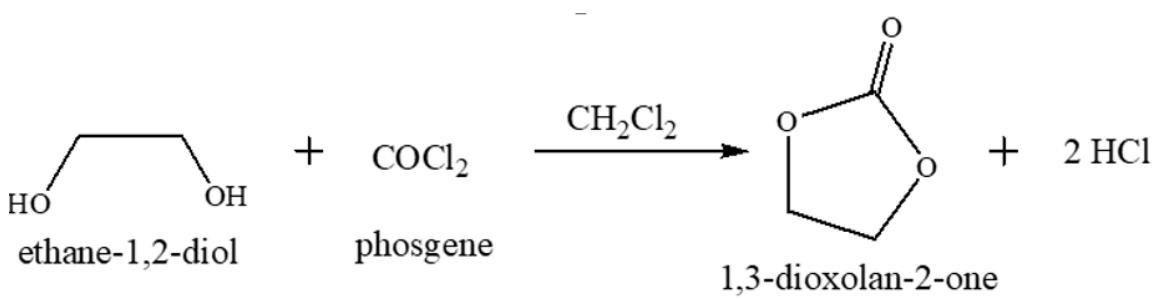

Scheme 1. Synthesis of organic carbonate by the conventional route.

By considering the economic point of view and avoid toxicity generation, the $\mathrm{CO}_{2}$ is a natural choice to phosgene as an alternate and the other advantage is that $\mathrm{CO}_{2}$ can be incorporated into epoxides without side products [45]. However, due to the inert nature of $\mathrm{CO}_{2}$, various catalysts were adopted to activate the epoxide [11]. The cycloaddition of $\mathrm{CO}_{2}$ to epoxide is shown below (Scheme 2).<smiles>[R]C1COC(=O)O1</smiles>

Scheme 2. Cycloaddition of $\mathrm{CO}_{2}$ to epoxide forming cyclic carbonate.

To increase cyclic carbonates yield from cycloaddition of $\mathrm{CO}_{2}$ and epoxides, a different kind of catalyst has been adopted. In the past decades, the wide range of homogeneous and heterogeneous catalysts have been developed to catalyze the so-called $\mathrm{CO}_{2}$ fixation process. Homogeneous catalysts, such as $\mathrm{CoCl}_{2}$ /onium salt [44], diimine $\mathrm{Ru}$ (II) complex [46], Al-salen-PEA [4], betaine-based quaternary ammonium ion and carboxylic acid [12], $\mathrm{N}, \mathrm{N}$-dimethyl formamide (DMF) [47,48], $\mathrm{SnCl}_{4}$-organic base [49], $\mathrm{Au} / \mathrm{Fe}(\mathrm{OH})_{3}$ $\mathrm{ZnBr}_{2} / \mathrm{Bu}_{4} \mathrm{NBr}$ [50], ionic liquid-highly cross linked polymer [51], $\mathrm{BrBu}_{3} \mathrm{PPEG}_{600} \mathrm{PBU}_{3} \mathrm{Br}$ [52], cellulose/KI [53], and Au/R201 [54] have also been studied.

Several heterogeneous catalysts, such as metal oxides; $\mathrm{MgO}[55,56], \mathrm{Nb}_{2} \mathrm{O}_{5}$ [43], Mg-Al oxide, guanidine-MCM-41 [57], Adeine-Pr-Al-SBA-15 [58], Cr-salen-SiO ${ }_{2}$ [13], Mn-salen-SiO 2 [42], ClAlPC-MCM-41 [59], 3-(2-hydroxyl-ethyl)-1-propyl imidazolium bromide-SBA-15, and zeolite-based organic-inorganic hybrid catalysts have also been investigated [55-66].

Ionic liquid (IL) is recently explored as efficient catalysts with growing importance over the past decades [64]. Since 2003, ILs have widely been adopted in the chemical industry as a solvent as well as catalysts for many fine chemical productions [60-65]. Hence, a quaternary ammonium ion together with a halide anion, $-\mathrm{OH}$, or a $-\mathrm{COOH}$ group with ionic liquid was considered as potential materials for heterogeneous catalysis.

\section{Summary}

The present review article described the effect of influential parameters such as temperature, pressure, and solvent on the conversion of cyclic epoxide into cyclic carbonate formation in presence of various ionic liquid modified hybrid catalysts. Another section describes the mechanisms insight into the activation of carbon dioxide and the ring-opening process in the process of substrate conversion and acidic/basic characteristics of the catalyst. 


\section{Results of Reaction Parameters and Influencing Factors for the Production of Cyclic Carbonates}

The production of cyclic carbonates depends on various parameters including catalyst and reaction parameters such as solvents, temperature, and pressure condition. The optimization of all the above parameters could produce maximum product yield. Table 1 summarizes studies that were carried out for cycloaddition of greenhouse gas conversion to styrene oxide (SO) on different types of catalysts [66-99]. The produce yield was higher due to the presence of both acid and base bifunctional groups present on the catalyst and it synergistically activates the cycloaddition reactions.

Table 1. Catalytic activity studies of cycloaddition of $\mathrm{CO}_{2}$ to styrene oxide using various homogeneous and heterogeneous catalysts.

\begin{tabular}{|c|c|c|c|c|c|c|c|c|}
\hline \multirow[b]{2}{*}{ Catalytic Materials ${ }^{a}$} & \multicolumn{4}{|c|}{ Reaction Conditions } & \multicolumn{3}{|c|}{ Reaction Results } & \multirow[b]{2}{*}{ References } \\
\hline & $\begin{array}{l}\text { Solvent or } \\
\text { Co-Catalyst }\end{array}$ & $\begin{array}{l}\mathrm{P}_{\mathrm{CO} 2} \\
\text { (bar) }\end{array}$ & $\begin{array}{c}\text { Temp. } \\
\left({ }^{\circ} \mathrm{C}\right)\end{array}$ & $\begin{array}{l}\text { Time } \\
\text { (h) }\end{array}$ & Yield (\%) & $\begin{array}{c}\text { Selectivity } \\
(\%)\end{array}$ & $\begin{array}{c}\text { Conversion } \\
(\%)\end{array}$ & \\
\hline Guanidine-MCM-41 & $\mathrm{CH}_{3} \mathrm{CN}$ & 50 & 140 & 70 & 90 & 92 & - & [11] \\
\hline Al-SBA-15-pr-Ade & - & 6.9 & 120 & 4 & 88.9 & 94.6 & 94 & [58] \\
\hline $\mathrm{Cr}$-salen-SiO 2 & $\mathrm{CH}_{2} \mathrm{Cl}_{2}$ & 100 & 80 & 6 & 74 & 100 & - & [13] \\
\hline Mn-salen- $\mathrm{SiO}_{2}$ & - & $35^{\mathrm{b}}$ & 140 & 3 & 95 & - & - & [42] \\
\hline ClAlPc-MCM-41 & $\mathrm{n}-\mathrm{Bu}_{4} \mathrm{NBr}$ & 40 & 110 & 2 & $384^{c}$ & - & - & [59] \\
\hline Al-salen-PEA & $\begin{array}{l}\text { n-Methyl } \\
\text { imidazole }\end{array}$ & 100 & 80 & 15 & 78 & 87.6 & 89 & [4] \\
\hline Betaine-based salt ${ }^{\mathrm{d}}$ & - & 80 & 140 & 8 & 96 & - & - & [12] \\
\hline & $\mathrm{CH}_{3} \mathrm{CN}$ & 6.9 & 120 & 8 & - & 98.2 & 88.4 & [60] \\
\hline MCM-41 e & - & 6.9 & 120 & 8 & - & 95.2 & 93.7 & {$[60]$} \\
\hline $\mathrm{Zn} / \mathrm{Ps}-\mathrm{IL}(\mathrm{Br})$ & - & 30 & 120 & 8 & 97.5 & - & - & [91] \\
\hline SalenRu(II) $\left(\mathrm{PPh}_{3}\right)_{2} / \mathrm{PTAT}^{\mathrm{f}}$ & Ethanol & 8.3 & 70 & 2 & 92 & - & - & [92] \\
\hline $\mathrm{CoCl}_{2} /$ onium salt & $\mathrm{CH}_{2} \mathrm{Cl}_{2}$ & 15 & 120 & 1 & $1238^{c}$ & - & - & [44] \\
\hline & $\mathrm{CH}_{3} \mathrm{CN}$ & 6.9 & 120 & 8 & - & 87 & 79.8 & [1] \\
\hline Ti-SBA-15-pr-Ade & - & 6.9 & 120 & 8 & - & 94.6 & 94 & [1] \\
\hline Diimine $\mathrm{Ru}(\mathrm{II})$ complex & - & 16 & 100 & 2 & 73.1 & - & - & [46] \\
\hline Ionic liquid-polymer & - & 60 & 110 & 7 & 79.1 & - & - & [50] \\
\hline Cellulose/KI & - & 20 & 110 & 9 & 98 & - & - & [53] \\
\hline HEPIMBr & - & 20 & 120 & 2 & 99.6 & - & 99.8 & [14] \\
\hline $\begin{array}{c}\text { Ionic liquid tetrabutylammonium } \\
\text { chloride }\end{array}$ & - & 9.7 & $100 \mathrm{~g}$ & 0.5 & 97.9 & - & - & {$[40]$} \\
\hline $\mathrm{Au} / \mathrm{Fe}(\mathrm{OH})_{3}-\mathrm{ZnBr}_{2} / \mathrm{Bu}_{4} \mathrm{NBr}$ & - & 40 & 80 & 10 & 53 & - & - & [50] \\
\hline $\mathrm{Co}(\mathrm{III})$ complex & DMAP & 20 & 120 & 3 & 85.8 & - & - & [38] \\
\hline SLPC & Toluene & 45 & 150 & 6 & 84.8 & - & - & [81] \\
\hline Co(III) Porphyrin/DMAP & $\mathrm{CH}_{2} \mathrm{Cl}_{2}$ & 20.7 & 120 & 4 & 97 & - & - & {$[82]$} \\
\hline MNP-Co-Porphyrin & $\mathrm{CH}_{2} \mathrm{Cl}_{2}$ & 10 & 25 & 36 & 48.7 & - & - & [83] \\
\hline $\mathrm{M}(\mathrm{TTMAPP}) \mathrm{I}_{4}(\mathrm{X}) \mathrm{M}=\mathrm{Co} ; \mathrm{X}=\mathrm{OAc}$ & - & 6.7 & 80 & 36 & 62.5 & - & - & {$[84]$} \\
\hline $\begin{array}{l}\text { Bis-(phenoxyiminato) } \\
\text { cobalt(III)/Lewis base }\end{array}$ & $\mathrm{CH}_{2} \mathrm{Cl}_{2}$ & 10 & 145 & 1 & $600 / 640^{c}$ & - & - & [44] \\
\hline $\begin{array}{c}\text { Metal porphyrin/phenyltrimethyl- } \\
\text { ammonium } \\
\text { tribromide }\end{array}$ & - & 6.9 & 20 & 10 & 20 & - & - & [85] \\
\hline $\mathrm{SnCl}_{4}$-organic base & - & 3.5 & 75 & 1.5 & 96 & - & - & [49] \\
\hline P-DVB-HEImBr & $\mathrm{Zn} \mathrm{I} 2$ & 20 & 140 & 5 & 98.9 & 96 & 23 & [68] \\
\hline SBA-15-IL1Br & & 20 & 110 & 3 & 80 & 99 & 80.8 & [91] \\
\hline Silica-immobilized & & 6 & 130 & 10 & 76.6 & 97 & 79 & [92] \\
\hline PDDA-Br & & 25 & 100 & 12 & 92.9 & - & - & [93] \\
\hline $\mathrm{KI} / \mathrm{PDA}$ & $\mathrm{OH}$ & 20 & 120 & 5 & 34.7 & 99 & 35 & [94] \\
\hline$\left(\mathrm{P}-\mathrm{Im}-\mathrm{C}_{4} \mathrm{H}_{8} \mathrm{Ph}_{3} \mathrm{P}\right) \mathrm{Br}_{2}$ & & 25 & 130 & 4 & 99.3 & 99.8 & 99.5 & [95] \\
\hline PPN(I) & & 1 & 100 & 7 & 89 & 97.8 & 95 & [95] \\
\hline PS-hexyl-MeI & & 12 & 120 & 12 & 96.7 & 100 & 98.9 & [98] \\
\hline PS-TBMAC & & 9 & 110 & 2 & 71 & - & - & [99] \\
\hline
\end{tabular}

a SLPC: supported liquid phase catalyst; pr: 3-chloro or 3-aminopropyltriethoxysilane; PEA: poly(ethylene glycol bismethacrylate); PTAT: phenyltrimethylammonium tribromide; $\mathrm{M}(\mathrm{TTMAPP}) \mathrm{I}_{4}(\mathrm{X})$ : bifunctional metalloporphyrins; Ade: adenine; ClAlPc: aluminum phthalocyanine; HEPIMBr: 3-(2-Hydroxyl-Ethyl)-Propylimidazolium bromide; MNP: magnetic nanoparticle; CS: chitosan; ChI: choline iodide; PDA: conjugated microporous polymer; Imi: imidazole; PDDA-Br: polydiallyldimethylammonium bromide; PPN(I): 4-Pyrrolidino(3-(trimethoxysilyl)propyl)pyridinium iodide; CNT: carbon nanotubes; PS: polystyrene-supported quaternized ammonium salt; PS-TBMAC: polymer-supported tributylmethylammonium chloride. ${ }^{\mathrm{b}}$ molar ratio of $\mathrm{CO}_{2}$ to styrene oxide. ${ }^{\mathrm{c}}$ turn over frequency $\left(\mathrm{h}^{-1}\right){ }^{\mathrm{d}}$ quaternary ammonium ion and carboxylic acid group. ${ }^{\mathrm{e}}$ bulk MCM-41 catalyst. ${ }^{\mathrm{f}}$ recrystallization in ethanol. ${ }^{g}$ microwave-irradiation method. 


\subsection{Effect of Influence of Reaction Temperature for Cycloaddition of Epoxides with $\mathrm{CO}_{2}$}

The reaction temperature is an important parameter in a catalytic reaction for an effective collision between molecules to enhance the bond-breaking step. Hence, the more molecular collision is the reason for the more yield of final products. Aresta et al. [26,41] reported the temperature effect on the production of styrene carbonate (SC) using $\mathrm{Nb}_{2} \mathrm{O}_{5}$ as a catalyst from styrene oxide by $\mathrm{CO}_{2}$ addition. Below $100{ }^{\circ} \mathrm{C}$, the reaction did not yield any product. However, it provides $80 \%$ yield at temperature of $135{ }^{\circ} \mathrm{C}$. Jutz et al. [40] studied the effect of reaction temperature on the performance of $\mathrm{Mn}$ (salen) $\mathrm{Br}$. The highest yield was obtained at $160{ }^{\circ} \mathrm{C}$, and with a further increase in temperature, the yield was dramatically reduced. This was attributed to changes in the phase distribution observed at higher reaction temperatures. Zhou et al. [11] reported that the reaction carried out at $140{ }^{\circ} \mathrm{C}$ results in the formation of propylene carbonate (PC) with the highest yield of $98 \%$. Increase in the temperature from 140 to $150{ }^{\circ} \mathrm{C}$ dropped the yield up to $78 \%$ due to problems of side product generation at high-temperature conditions. Bai et al. $[83,84]$ reported that in some instances, high-temperature conditions are causing the catalyst to decompose resulting in a decrease in propylene carbonate (PC) yield [84]. Qiao et al. [91] explained that styrene oxide (SO) is difficult to convert to styrene carbonate (SC) compared to all other epoxides due to the lower reactivity of $\beta$-carbon atom. They found that the temperature of $120^{\circ} \mathrm{C}(98 \%)$ with suitable catalyst was the best-optimized condition than the high-temperature condition $\left(130{ }^{\circ} \mathrm{C}(\sim 80 \%)\right.$ and $\left.140{ }^{\circ} \mathrm{C}(\sim 95 \%)\right)$.

Recently, Lee et al. [98] studied the cycloaddition reaction between ally glycidyl ether (AGE) and carbon dioxide using PS-hexyl-Methyl iodide at 12 bar of total pressure and different temperature conditions. They reported that the yield of allyl glycidyl carbonate (AGC) increases from 80 to $140{ }^{\circ} \mathrm{C}$, and it decreased with a further increase in the temperature to $160^{\circ} \mathrm{C}$. The yield decreased was due to the generation of oligomers and other side products like 3-allyl oxy-1,2-propanediol. Zhong (2014) et al. [100] studied and reported the effect of temperature in the range between 120 and $160^{\circ} \mathrm{C}$ for propylene carbonate formation. The yield of PC in the presence of 0.78 and $13.7 \mathrm{~m} / \mathrm{mol}$ of DMF solvents for comparative purpose was studied. They found that the usage of a large amount of DMF was favorable to provide a higher yield at the lower reaction temperature.

\subsection{Effect of Influence of Reaction Pressure Condition for Cycloaddition of Epoxides with $\mathrm{CO}_{2}$}

The reaction pressure of the carbon dioxide insertion has been established as one of the most crucial and critical conditions for affecting the epoxide cycloaddition reaction [91-98]. The inserted $\mathrm{CO}_{2}$ acts as an important reactant for all catalytic transformations [42]. Two phases are established in the reaction system; the bottom phase is rich with epoxide and the top phase is enriched with $\mathrm{CO}_{2}$. According to Xie et al. (2007), the reactant $\mathrm{CO}_{2}$ favors the reaction when the bottom phase is under high pressure. However, the above condition is not favorable for the high-pressure reactions (120 bar) as concentration of epoxide for example propylene oxide [49].

Ghosh et al. [36] reported that at lower pressure (7 bar), the catalyst retains moderate reaction activity turn over frequency (TOF) of $312 \mathrm{~h}^{-1}$ and with increasing pressure up to $20 \mathrm{bar}$, increased TOF value of $351 \mathrm{~h}^{-1}$ was observed. However, the pressure more than 20 bar results in diminishes overall reactivity due to polarity and solubility problem of the catalysts. Qiao et al. [91] reported different pressure conditions, such as mild pressure (15 bar), medium pressure ( $80 \mathrm{bar}$ ), and supercritical pressure (140 bar), for the styrene oxide with $\mathrm{CO}_{2}$ cycloaddition reactions. This was due to changes in the phase from gas to supercritical fluid, where a part of styrene oxide (SO) dissolves in the supercritical condition. On the other hand, Wang, et. al (2017) [65] approach was for the same reaction but different perspective, i.e., introduction of high concentration of $\mathrm{CO}_{2}$ dissolves within a substrate or "liquefies" the formation of intermediate complex.

Xiang et al. (2009) [52] reported that the many oligomers were produced as the side products such as propylene oxide and styrene oxide due to insertion of $\mathrm{CO}_{2}$ at high pressure 
in a solvent-less condition. Jutz et al. $[40,53]$ reported that a ratio of 1:4 (epoxide: $\mathrm{CO}_{2}$ ) was the best reactant ratio condition instead of 1:16 for conversion of both epoxides.

\subsection{Effect of Influence of Solvent for Cycloaddition of Epoxides with $\mathrm{CO}_{2}$}

A variety of solvents are adopted to synthesis cyclic carbonate from cycloaddition reaction. A solvent plays a key role in minimizing carbonaceous deposits on the catalyst surface. [55]. Aresta et al. [26,41] exploited that the $N, N$-dimethyl formamide (DMF) alone yields $34.7 \%$ of styrene carbonate at 50 bar pressure of $\mathrm{CO}_{2}$ and predict that amide group was a good promoter. Di-methyl acetamide (DMA) produced SC about $28 \%$ yield without the catalyst at 50 bar pressure and at temperature of $135^{\circ} \mathrm{C}$ for $12 \mathrm{~h}$. The role of DMF in the cycloaddition of epoxides mechanism and transformation is as follows (Scheme 3).

(a)<smiles>[R][N+]([R])(CCC)CCC(=O)O</smiles>

(b)<smiles>[R]N(CCC1([R])CO1)C([2H])=O</smiles><smiles>[R]N1C(=O)[CH]OC1O</smiles>

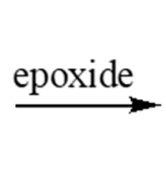<smiles>[R]C1CCOCC(=O)OCC1C(=O)O</smiles>



Scheme 3. (a) Role of $N, N$-dimethyl formamide (DMF) ) (a) initial $\mathrm{CO}_{2}$ activation; (b) initial epoxide activation, in the cycloaddition of epoxides [43] (modified images and cited the related reference).

According to the mechanism, role of amide is to facilitate the nucleophilicity of the respective oxygen atoms in $\mathrm{CO}_{2}$ or epoxides. From the results, it is evident that the methylene chloride could contribute to stabilize the polar or ionic intermediates through the dipole effect, i.e., $\mathrm{C}^{\delta-}-\mathrm{H}^{\delta+}$ and $\mathrm{C}^{\delta+}-\mathrm{Cl}^{\delta-}$. The cooperative solvation effect occurred in the presence of tetrachloro methane and ethanol-like additive used along with DMF for cycloaddition reactions. Kawanami et al. (2000) [45] used supercritical condition (sc) to study the effect of DMF as a catalyst and solvent on epoxide formation, which is dissolved in DMF-scCO ${ }_{2}$. Recently, Zhong (2000) et al. [100] utilized DMF as cocatalyst with $\mathrm{ZnBr}_{2}$ as a catalyst for cycloaddition reaction of propylene oxide with carbon dioxide. In their study, they have observed that DMF acted as a solvent as well as carbon dioxide activator. Both high conversion and $100 \%$ selectivity was obtained at $150{ }^{\circ} \mathrm{C}$ and pressure condition of 30 bar with very quick reaction time of $10 \mathrm{~min}$ [100]. Alvaro (2004) et al. [12] used $0.4 \mathrm{~mL}$ dichloromethane (DMC) or dimethyl carbonate as a cosolvent to enhance product solubility in the supercritical medium and it serves as a cocatalyst as well. The results showed 70\% conversion and $100 \%$ selectivity in presence of $\mathrm{Cr}$-salen base catalyst under supercritical condition (100 bar, $80^{\circ} \mathrm{C}$, reactor volume $=50 \mathrm{~m}, 6 \mathrm{~h}$ reaction time).

A new approach was taken by Jiang et al. [46] in order to study the solvent effect for the synthesis of chloropropene carbonate from epichlorohydrin. Protic alcohols (methanol and ethanol) acted as good solvent for the formation of chloropropene carbonate with $90 \%$ and $82 \%$ yield. However, higher molecular weight alcohol such as benzyl alcohol was found to give less productivity yield $(12 \%)$, whereas the same reaction carried out at $110{ }^{\circ} \mathrm{C}$ for $20 \mathrm{~h}$ with DMF as the solvent resulted in achieving for highest yield ( $\mathrm{f}>99 \%$ ). 


\section{Discussion of the Mechanism Insight of Cycloaddition of Epoxides with $\mathrm{CO}_{2}$}

\subsection{Activation of $\mathrm{CO}_{2}$ for Cycloaddition of Epoxides}

Lu et al. [59] reported that aluminum pthalocyanine complex formation on MCM-41 support for the cycloaddition reaction of epoxides They observed that $\mathrm{CO}_{2}$ activated through nucleophilic attack at the carbon atom of $\mathrm{CO}_{2}$ by the alcoholate group $\left(-\mathrm{OCH}_{2} \mathrm{CH}_{2} \mathrm{Br}\right)$. The weak interaction between the central metal ion of pthalocyanine complex and the lone pairs oxygen in $\mathrm{CO}_{2}$ makes synergistic mechanism. The halide intramolecular substitution facilitate the epoxide into cyclic carbonates. In another related study, Barbarini et al. [10] argued that the mechanism of $\mathrm{CO}_{2}$ activation through the formation of the zwitterion compound. Scheme 4 shows that the $\mathrm{CO}_{2}$ adds to the epoxide via nucleophilic attack.<smiles>CN1CCCN2CCCN=C12</smiles>

guanidine MTBD<smiles>CN1CCCN2CCCN(C(=O)O)C12</smiles>

Activated $\mathrm{CO}_{2}$ carbamate anion

Scheme 4. Hypothesized 7-Methyl-1,5,7-triazabicyclo [4.4.0]dec-5-ene (MTBD)-promoted $\mathrm{CO}_{2}$ activation [11].

Srivastava et al. 2005 [1] exploited at first regarding the physico-chemical properties of the model catalyst in the activation of $\mathrm{CO}_{2}$ molecules. Surface absorbing nature of $\mathrm{CO}_{2}$ on catalyst was studied by Ft-IR spectroscopy. The $\mathrm{CO}_{2}$ interacted with the amine functional groups in functionalized [SBA-15- $p r$-Ade(adenine) and Ti-SBA-15- $p r$-Ade(adenine)] was identified and confirmed by presence of the carbamate bands at 1609 and $1446 \mathrm{~cm}^{-1}$.

The efficient Epichlorohydrin conversion was obtained (62.3\%) after functionalization of SBA-15 with adenine group compared to bulk SBA- 15 (1.5\%). This increased in conversion was related to the intensity of the band at $1609 \mathrm{~cm}^{-1}$ ascribed due to $\mathrm{CO}_{2}$ bonded with amine sites, which recognize the importance of such sites for $\mathrm{CO}_{2}$ activation. In a related study, Srivastava et al. [77,86] exploited and compared the importance of the basic sites present in the catalysts such as alkyl amines $\left(-\mathrm{NH}_{2}\right)$, adenine (Ade), imidazole (Im) and guanine (Gua) to activation process of carbon dioxide. Different types of coordination modes of $\mathrm{CO}_{2}$ was discussed in detail in the past and its well known in the field of carbon dioxide chemistry [75].

Scheme 6 shows the stability of the activated $\mathrm{CO}_{2}$ complex formation occurs on the basic amine sites at the catalyst surface decreased as follows: primary $>$ secondary $>$ tertiary amines $[75,77,86]$. The formation of carbamate anions from different type of amine groups are demonstrated. The metal- electron deficient part of the catalyst facilitates the reaction rate for the formation of cyclic carbamate ions.

In Scheme 5 it is more clearly explained the role activation of $\mathrm{CO}_{2}$ for their efficient conversion towards carbon dioxide activation process.

From their point of view, Scheme 5 shows the stability of the activated $\mathrm{CO}_{2}$ complex formation that occurring on the basic amine sites at the surfaces of catalyst decreased as follow: primary $>$ secondary $>$ tertiary amines $[75,77,86]$. The formation of carbamate anions from different types of amine groups are demonstrated. The metal-electron deficient part of the catalyst facilitates the reaction rate for the formation of cyclic carbamate ions. 
(a) $\mathrm{CO}_{2}$ activation at primary amines:

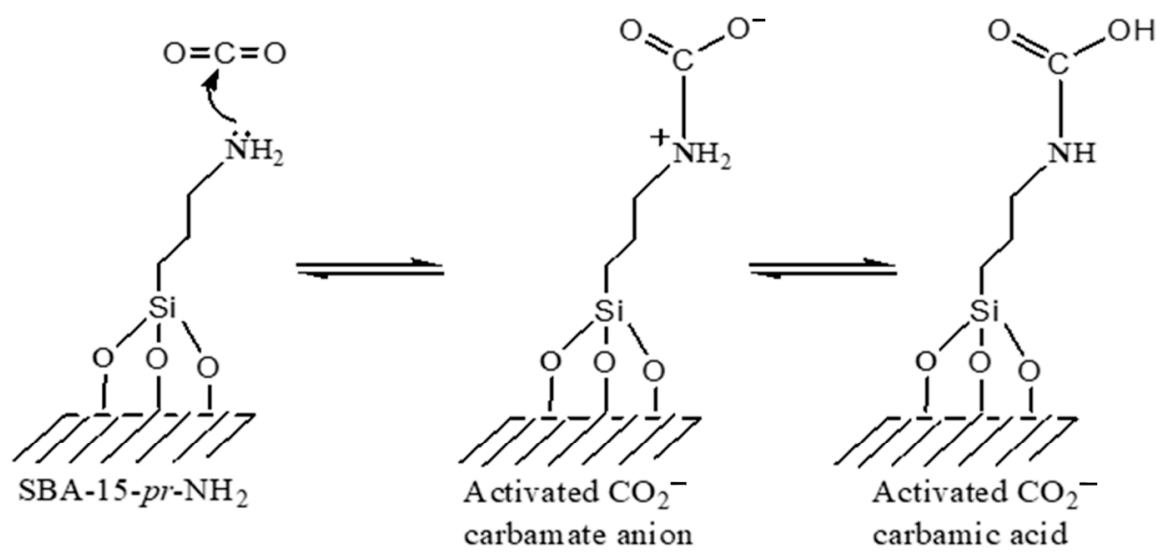

(b) $\mathrm{CO}_{2}$ activation at secondary amines:

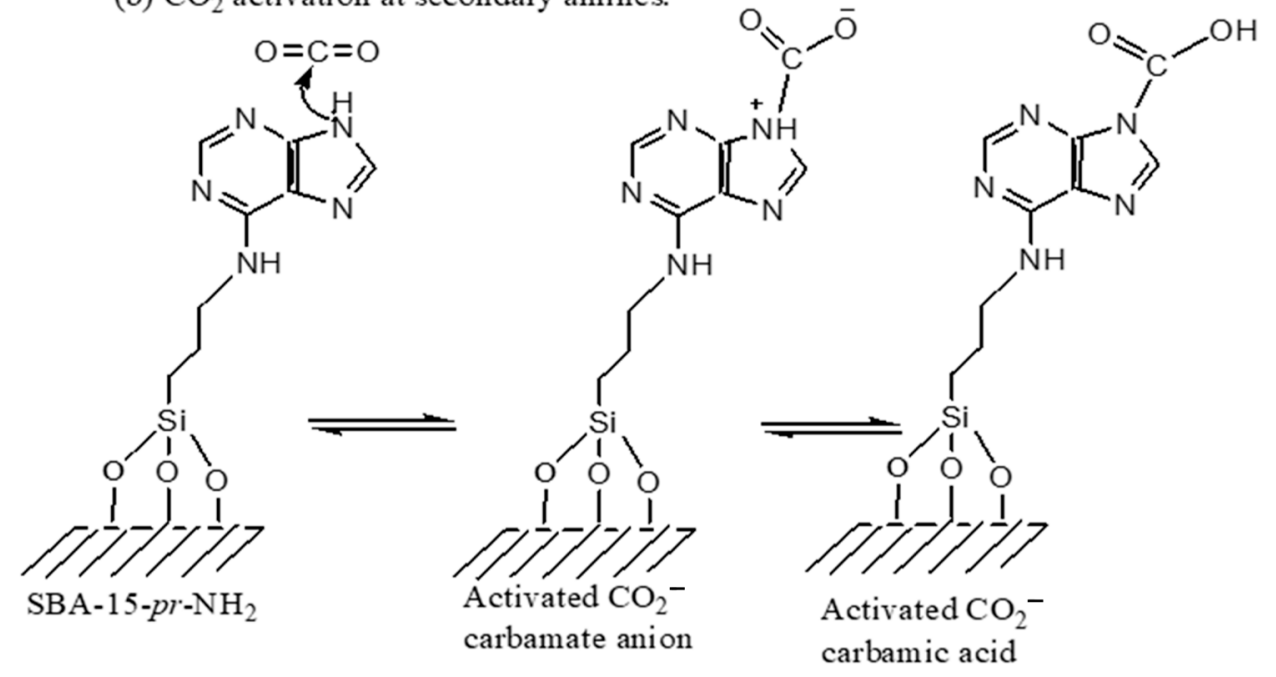

(c) $\mathrm{CO}_{2}$ activation at tertiary amines:

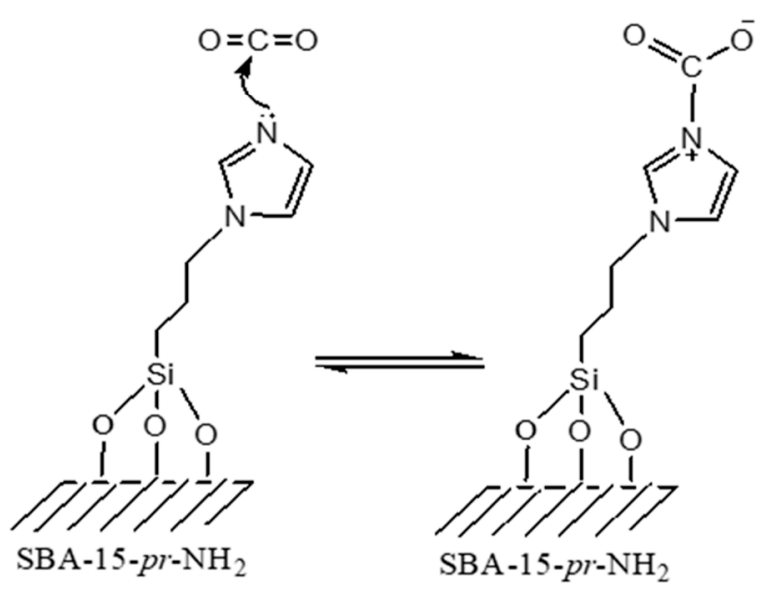

Scheme 5. $\mathrm{CO}_{2}$ activation through primary, secondary, and tertiary amines $[77,86]$.

\subsection{Ring Opening of Epoxide}

The ring-opening mechanism of the epoxide is described in two ways such as (i) Lewisacid catalyzed cleavage and (ii) Lewis-base catalyzed cleavage. Bu et al. (2007) [101] found that the ruthenium complex $\left(\left(2,2^{\prime}\right.\right.$-bipy $\left.) \mathrm{RuCl}_{3}\left(\mathrm{CH}_{3} \mathrm{OH}\right)\right)$ supported by cetyl-trimethyl ammonium chloride (CTAC) catalyzes propylene oxide (PO) in the presence of $\mathrm{CO}_{2}$ and achieved $100 \%$ yield for propylene carbonate (PC). In the above catalyst system, Ru acts as 
a Lewis-acid to activate the PO to form adduct of Ru-PO. CTAC addition enhances reaction rate and strikes the less sterically hindered carbon to break the epoxide ring while forming the oxy-anion species.

Bai et al. $[83,96]$ reported that the bi-functional metal porphyrins $\mathrm{M}(\mathrm{TTMAPP}) \mathrm{I}_{4}(\mathrm{X})$ $\left(\mathrm{M}=\mathrm{Co}, \mathrm{Mn}, \mathrm{Fe}\right.$, and $\mathrm{Cr} ; \mathrm{X}=\mathrm{OAc}, \mathrm{CCl}_{3} \mathrm{COO}, \mathrm{CF}_{3} \mathrm{COO}, \mathrm{OTs}, \mathrm{I}, \mathrm{Cl}$, and $\mathrm{Br}$ ) were highly efficient catalysts for the respective cycloaddition (formation of propylene carbonate). In the above catalyst system, metal ion incorporation acts as a Lewis acid center to facilitate the catalytic reaction rate. The order of activity of the catalysts was $\mathrm{Co}>\mathrm{Mn}>\mathrm{Fe}>$ $\mathrm{Cr}$. The catalytic activity of cobalt porphyrin decreased with different counter ions as follows: $\mathrm{CH}_{3} \mathrm{COO}^{-}>\mathrm{I}^{-}>\mathrm{Cl}^{-}>\mathrm{Br}^{-}>\mathrm{OTs}^{-}>\mathrm{CF}_{3} \mathrm{COO}^{-}>\mathrm{CCl}_{3} \mathrm{COO}^{-}$. Barbarini et al. [10] reported mesoporous silica (MCM-41) with hexagonal morphology in which $\mathrm{Si}-\mathrm{OH}$ (hydroxyl and silanol functionalized)-supported guanidine catalysts are studied for cycloaddition reactions. The enhanced reactivity was obtained due to mechanisms involved in hydrogen bonding. Zhou et al. [11] studied the mechanism of cyclic carbonate formation in the presence of betaine (HBetX) and choline cation (ChoX) catalyst. They compared the anion effect and hydroxyl and carboxyclic acid group activation towards catalyst function. The order of reactivity for PC conversion and yield decreased as follows: $\mathrm{Cl}^{-}>\mathrm{BF}_{4}{ }^{-}>\mathrm{PF}_{6}{ }^{-}$. The role of leaving group ability has also been studied, and the activity follows in this order: $\mathrm{I}^{-}>\mathrm{Br}^{-}>\mathrm{Cl}^{-}$. Adopting better nucleophilic anions could improve the epoxide ring opening/breaking efficiency of the catalyst.

The carboxylic acid group is found to be best for ring-opening mechanism with respect to suitable halide anions. The reason behind the halide anions to activate the ring opening is due to presence of stronger BrøØnsted acid and thereby involved in hydrogen bonding. Scheme 6 shows the reaction mechanism for the cycloaddition reaction and its halide anion interaction.

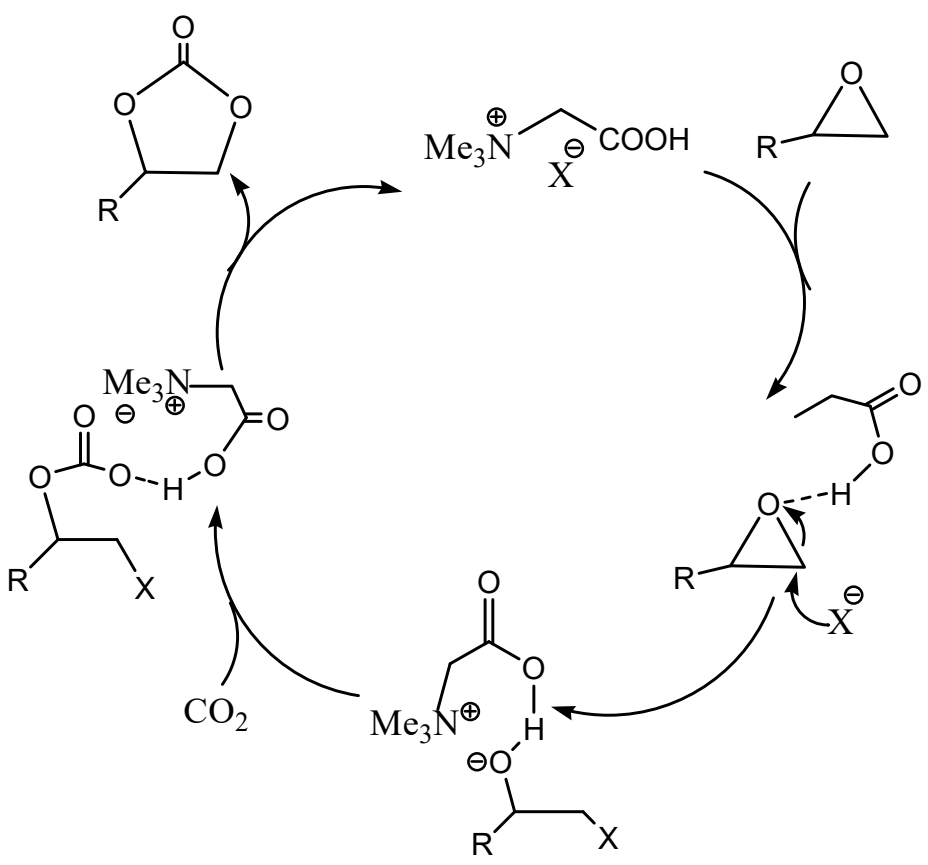

Scheme 6. The plausible cycloaddition reaction mechanism for epoxide ring opening with $\mathrm{CO}_{2}$ by betaine (HBetX) catalysts [11].

Dai et al. [80,97] reported 3-(2-hydroxyl-ethyl)-1-propyl imidazolium bromide-SBA-15 (HEPIMBr), which is another type of mesoporous silica. The efficient synthesis of cyclic carbonates was achieved under mild conditions without solvent and in the absence of a co-catalyst.

Biopolymer chitosan-grafted quaternary phosphonium ionic liquid (CS-( $\left.\mathrm{BuPh}_{3} \mathrm{P}\right) \mathrm{Br}$ ) was reported as an excellent catalyst [98]. The authors proposed that the bromide anion of 
the catalyst played a major role in epoxy ring opening activated by the hydroxyl groups and phosphonium cation interaction. The same type of catalysts was developed by reported hydroxyl, carboxyl, and amino-functionalized phosphonium-based ionic liquid catalyst. They observed that a similar mechanism as mentioned above for the opening of the epoxide ring via polarization of epoxide C-O bond [90-98]. Excellent selectivity and good yield were obtained for cyclic carbonates under suitable or optimizable reaction conditions [90-101]. The following yields were obtained for the each cyclic carbonates such as epichlorohydrine $(97.0 \%)$,) glycidol $(98.3 \%)$, styrene oxide $(98.8 \%)$, phenyl glycidyl ether $(96.7 \%)$ for allyl glycidyl ether $(97.5 \%$, ) and 1,2-epoxyhexane (100\% for) at the reaction time of three hours (3 h) $[101,102]$.

Ramalingam et al. [102] and our group recently reported halide ion-modified mesoporous silica catalysts for solvent- free cycloaddition of styrene oxide with $\mathrm{CO}_{2}$. For above reaction, imidazole was first immobilized on MCM-41 (derived from biomass materials) using 3-chloropropyltriethoxysilane (CPTES) as the anchoring agent followed by alkylation with 1,2-dibromoethane at $110{ }^{\circ} \mathrm{C}$. The prepared catalyst was mentioned as MCM-41-Imi/Br. The catalyst was used in the cycloaddition of styrene oxide, glycidol, epichlorohydrin and phenyl glycidyl ether, and allyl glycidyl ether.

The halide ion $(\mathrm{Br})$ and the tertiary amine from imidazole anchored over mesoporous support (MCM-41-Imi/Br) involved in the ring opening and activation of $\mathrm{CO}_{2}$. In Scheme 7, the mechanism of ring opening of the epoxide carried out by a nucleophilic attack by the bromide ion at the less sterically hindered $\beta$-carbon resulted to the formation of haloalkoxy species.


Styrenc carbonate

Scheme 7. Mechanism of the halide ion $(\mathrm{Br})$ and the tertiary amine from imidazole anchored over mesoporous support (MCM-41-Imi/Br) catalysts on cycloaddition of epoxide with $\mathrm{CO}_{2}$. 


\section{Conclusions}

The present review explained the different types of porous and mesoporous solid acid-base and ionic liquid-modified mesoporous catalysts for the effective conversion for cycloaddition reaction of various epoxide with $\mathrm{CO}_{2}$. In addition, the influence of various parameters, such as reaction temperature, pressure, and usage of solvents or solvent-free conditions, is discussed.

Both excellent selectivity and good yield were obtained for cyclic carbonates under tuned reaction conditions by ionic liquid immobilized MCM-41 catalyst. The higher yields were obtained for the conversion of cyclic epoxides. The above higher conversion proves that the value of the development of ionic liquid-based mesoporous catalytic materials and their future applications. The mechanism insight of ring opening of epoxide at various catalyst systems has also been discussed. The Ft-IR spectroscopy is very useful to exploit the activation mechanism of $\mathrm{CO}_{2}$ for cycloaddition reaction using the various aminefunctionalized solid catalyst. Hence, the development of a hybrid composite catalyst based on ionic liquid could be the potential material for direct usage of emerging greenhouse gas for various chemical processes.

Author Contributions: Conceptualization, R.J.R. and J.N.A., M.K.G.; methodology, R.J.R. and J.N.A.; validation, G.P., H.A.A.-L., P.A., investigation, R.A., F.A., M.D.W.; resources, R.J.R.; writing—original draft preparation, RJR and J.N.A.; M.K.G.; writing-R.J.R. and J.N.A., M.K.G.: project administration, R.J.R., F.A., P.A., R.A, H.A.A.-L.; funding acquisition R.J.R., G.P. All authors have read and agreed to the published version of the manuscript.

Funding: The author (JNA) thank and express gratitude to USM, Penang, Malaysia for the support of his post-doctoral research work. The authors are also thanks this research was funded by Deputyship for Research \& Innovation, "Ministry of Education" in Saudi Arabia for funding this research work through the project number IFKSURP-335, Kingdom of Saudi Arabia.

Acknowledgments: The authors acknowledge the Deputyship for Research \& Innovation, “Ministry of Education" in Saudi Arabia for funding this research work through the project number IFKSURP-335.

Conflicts of Interest: The authors declare that they have no known competing financial interest or personal relationships that could have appeared to influence the work reported in this paper.

\section{References}

1. Srivastava, R.; Srinivas, D.; Ratnasamy, P. $\mathrm{CO}_{2}$ activation and synthesis of cyclic carbonates and alkyl/arylcarbamates over adenine-modified Ti-SBA-15 solid catalysts. J. Catal. 2005, 233, 1-15. [CrossRef]

2. Luo, Y.; Ben, H.; Wu, Z.; Nie, K.; Han, G.; Jiang, W. Impact of $\mathrm{CO}_{2}$ on pyrolysis products of bituminous coal and platanus sawdust. Polymers 2019, 11, 1370. [CrossRef] [PubMed]

3. Hong, D.; Si, T.; Li, X.; Guo, X. Reactive molecular dynamic simulations of the $\mathrm{CO}_{2}$ gasification effect on the oxy-fuel combustion of Zhundong coal char. Fuel Process. Technol. 2020, 199, 106305. [CrossRef]

4. Alvaro, M.; Baleizao, C.; Carbonell, E.; El Ghoul, M.; García, H.; Gigante, B. Polymer-bound aluminium salen complex as reusable catalysts for $\mathrm{CO}_{2}$ insertion into epoxides. Tetrahedron 2005, 61, 12131-12139. [CrossRef]

5. McGee, M. What the World Needs to Watch. Available online: http:/ / co2now.org/ (accessed on 20 June 2020).

6. Leung, D.Y.C.; Caramanna, G.; Maroto-Valer, M.M. An overview of current status of carbon dioxide capture and storage technologies. Renew. Sustain. Energy Rev. 2014, 39, 426-443. [CrossRef]

7. Takht Ravanchi, M.; Sahebdelfar, S. Carbon dioxide capture and utilization in petrochemical industry: Potentials and challenges. Appl. Petrochem. Res. 2014, 4, 63-77. [CrossRef]

8. Al-Mamoori, A.; Krishnamurthy, A.; Rownaghi, A.A.; Rezaei, F. Carbon capture and utilization update. Energy Technol. 2017, 5, 834-849. [CrossRef]

9. Liu, J.; Wang, A.; Jing, $\mathrm{H}$. $\mathrm{TiO}_{2}$-based green heterogeneous catalysts for the cycloaddition of $\mathrm{CO}_{2}$ to epoxides. Chin. J. Catal. 2014, 35, 1669-1675. [CrossRef]

10. Barbarini, A.; Maggi, R.; Mazzacani, A.; Mori, G.; Sartori, G.; Sartorio, R. Cycloaddition of $\mathrm{CO}_{2}$ to epoxides over both homogeneous and silica-supported guanidine catalysts. Tetrahedron Lett. 2003, 44, 2931-2934. [CrossRef]

11. Zhou, Y.; Hu, S.; Ma, X.; Liang, S.; Jiang, T.; Han, B. Synthesis of cyclic carbonates from carbon dioxide and epoxides over betaine-based catalysts. J. Mol. Catal. A Chem. 2008, 284, 52-57. [CrossRef]

12. Alvaro, M.; Baleizao, C.; Das, D.; Carbonell, E.; García, H. $\mathrm{CO}_{2}$ fixation using recoverable chromium salen catalysts: Use of ionic liquids as cosolvent or high-surface-area silicates as supports. J. Catal. 2004, 228, 254-258. [CrossRef] 
13. Noh, J.; Chang, J.-S.; Park, J.-N.; Lee, K.Y.; Park, S.-E. $\mathrm{CO}_{2}$ utilization for the formation of styrene from ethylbenzene over zirconia-supported iron oxide catalysts. Appl. Organomet. Chem. 2000, 14, 815-818. [CrossRef]

14. Song, C. Global challenges and strategies for control, conversion and utilization of $\mathrm{CO}_{2}$ for sustainable development involving energy, catalysis, adsorption and chemical processing. Catal. Today 2006, 115, 2-32. [CrossRef]

15. Hutchings, G. Catalyst Synthesis Using Supercritical Carbon Dioxide: A Green Route to High Activity Materials. Top. Catal. 2009, 52, 982-987. [CrossRef]

16. Peters, M.; Köhler, B.; Kuckshinrichs, W.; Leitner, W.; Markewitz, P.; Müller, T.E. Chemical Technologies for Exploiting and Recycling Carbon Dioxide into the Value Chain. ChemSusChem 2011, 4, 1216-1240. [CrossRef]

17. Koohestanian, E.; Sadeghi, J.; Mohebbi-Kalhori, D.; Shahraki, F.; Samimi, A. A novel process for $\mathrm{CO}_{2}$ capture from the flue gases to produce urea and ammonia. Energy 2018, 144, 279-285. [CrossRef]

18. Huo, Z.; Hu, M.; Zeng, X.; Yun, J.; Jin, F. Catalytic reduction of carbon dioxide into methanol over copper under hydrothermal conditions. Catal. Today 2012, 194, 25-29. [CrossRef]

19. Iijima, T.; Yamaguchi, T. Efficient regioselective carboxylation of phenol to salicylic acid with supercritical $\mathrm{CO}_{2}$ in the presence of aluminium bromide. J. Mol. Catal. A Chem. 2008, 295, 52-56. [CrossRef]

20. Leitner, W. Carbon Dioxide as a Raw Material: The Synthesis of Formic Acid and Its Derivatives from $\mathrm{CO}_{2}$. Angew. Chem. Int. Ed. Engl. 1995, 34, 2207-2221. [CrossRef]

21. Darensbourg, D.J.; Holtcamp, M.W.; Struck, G.E.; Zimmer, M.S.; Niezgoda, S.A.; Rainey, P.; Robertson, J.B.; Draper, J.D.; Reibenspies, J.H. Catalytic Activity of a Series of Zn (II) Phenoxides for the Copolymerization of Epoxides and Carbon Dioxide. J. Am. Chem. Soc. 1998, 121, 107-116. [CrossRef]

22. Muthuraj, R.; Mekonnen, T. Recent progress in carbon dioxide $\left(\mathrm{CO}_{2}\right)$ as feedstock for sustainable materials development: Co-polymers and polymer blends. Polymer 2018, 145, 348-373. [CrossRef]

23. Ye, S.; Wang, S.; Lin, L.; Xiao, M.; Meng, Y. $\mathrm{CO}_{2}$ derived biodegradable polycarbonates: Synthesis, modification and applications. Adv. Ind. Eng. Polym. Res. 2019, 2, 143-160. [CrossRef]

24. Forest, C.; Chaumont, P.; Cassagnau, P.; Swoboda, B.; Sonntag, P. Polymer nano-foams for insulating applications prepared from $\mathrm{CO}_{2}$ foaming. Prog. Polym. Sci. 2015, 41, 122-145. [CrossRef]

25. Mazari, S.A.; Hossain, N.; Basirun, W.J.; Mubarak, N.M.; Abro, R.; Sabzoi, N.; Shah, A. An overview of catalytic conversion of $\mathrm{CO}_{2}$ into fuels and chemicals using metallic organic frameworks. Process. Saf. Environ. Prot. 2020. [CrossRef]

26. Aresta, M.; Dibenedetto, A. Utilisation of $\mathrm{CO}_{2}$ as a chemical feedstock: Opportunities and challenges. Dalton Trans. 2007, 28, 2975-2992. [CrossRef]

27. Tiwari, D.; Bhunia, H.; Bajpai, P.K. Adsorption of $\mathrm{CO}_{2}$ on $\mathrm{KOH}$ activated, $\mathrm{N}$-enriched carbon derived from urea formaldehyde resin: Kinetics, isotherm and thermodynamic studies. Appl. Surf. Sci. 2018, 439, 760-771. [CrossRef]

28. Yu, J.; Guo, M.; Muhammad, F.; Wang, A.; Zhang, F.; Li, Q.; Zhu, G. One-pot synthesis of highly ordered nitrogen-containing mesoporous carbon with resorcinol-urea-formaldehyde resin for $\mathrm{CO}_{2}$ capture. Carbon 2014, 69, 502-514. [CrossRef]

29. Sajeeb, A.M.; Babu, C.S.; Arif, M.M. Evaluation of Mechanical Properties of Natural Fiber Reinforced Melamine Urea Formaldehyde (MUF) Resin Composites. Mater. Today: Proc. 2018, 5, 6764-6769. [CrossRef]

30. Ma, C.-l.; Wang, Z.-r.; Hu, Z.-h.; Wang, Y.-h.; Zhao, Y.; Shi, J. Preparation of submicron monodisperse melamine resin microspheres and nitrogen-doped carbon microspheres derived from them. New Carbon Mater. 2020, 35, 269-285. [CrossRef]

31. Kosugi, Y.; Imaoka, Y.; Gotoh, F.; Rahim, M.A.; Matsui, Y.; Sakanishi, K. Carboxylations of alkali metal phenoxides with carbon dioxide. Org. Biomol. Chem. 2003, 5, 817-821. [CrossRef]

32. Tran, P.H.L.; Wang, T.; Yin, W.; Tran, T.T.D.; Nguyen, T.N.G.; Lee, B.-J.; Duan, W. Aspirin-loaded nanoexosomes as cancer therapeutics. Int. J. Pharm. 2019, 572, 118786. [CrossRef] [PubMed]

33. Zimmermann, K.C.; Waterhouse, N.J.; Goldstein, J.C.; Schuler, M.; Green, D.R. Aspirin Induces Apoptosis through Release of Cytochrome c from Mitochondria. Neoplasia 2000, 2, 505-513. [CrossRef] [PubMed]

34. Huang, Z.; Chiew, Y.C.; Lu, W.-D.; Kawi, S. Solubility of aspirin in supercritical carbon dioxide/alcohol mixtures. Fluid Phase Equilib. 2005, 237, 9-15. [CrossRef]

35. The Keeling Curve. 2020. Available online: https://www.nationalgeographic.org/encyclopedia/keeling-curve/ (accessed on 20 November 2020).

36. Ghosh, A.; Ramidi, P.; Pulla, S.; Sullivan, S.Z.; Collom, S.L.; Gartia, Y.; Munshi, P.; Biris, A.S.; Noll, B.C.; Berry, B.C. Cycloaddition of $\mathrm{CO}_{2}$ to Epoxides Using a Highly Active Co (III) Complex of Tetraamidomacrocyclic Ligand. Catal. Lett. 2010, 137, 1-7. [CrossRef]

37. Khoshro, H.; Zare, H.R.; Namazian, M.; Jafari, A.A.; Gorji, A. Synthesis of cyclic carbonates through cycloaddition of electrocatalytic activated $\mathrm{CO}_{2}$ to epoxides under mild conditions. Electrochim. Acta 2013, 113, 263-268. [CrossRef]

38. Dharman, M.M.; Choi, H.-J.; Park, S.-W.; Park, D.-W. Microwave Assisted Synthesis of Cyclic Carbonate Using Homogeneous and Heterogeneous Ionic Liquid Catalysts. Top. Catal. 2010, 53, 462-469. [CrossRef]

39. Zalomaeva, O.V.; Maksimchuk, N.V.; Chibiryaev, A.M.; Kovalenko, K.A.; Fedin, V.P.; Balzhinimaev, B.S. Synthesis of cyclic carbonates from epoxides or olefins and $\mathrm{CO}_{2}$ catalyzed by metal-organic frameworks and quaternary ammonium salts. J. Energy Chem. 2013, 22, 130-135. [CrossRef]

40. Jutz, F.; Grunwaldt, J.-D.; Baiker, A. Mn (III)(salen)-catalyzed synthesis of cyclic organic carbonates from propylene and styrene oxide in "supercritical" $\mathrm{CO}_{2}$. J. Mol. Catal. A Chem. 2008, 279, 94-103. [CrossRef] 
41. Aresta, M.; Dibenedetto, A.; Gianfrate, L.; Pastore, C. Nb (V) compounds as epoxides carboxylation catalysts: The role of the solvent. J. Mol. Catal. A Chem. 2003, 204-205, 245-252. [CrossRef]

42. Sibaouih, A.; Ryan, P.; Leskela, M.; Rieger, B.; Repo, T. Facile synthesis of cyclic carbonates from $\mathrm{CO}_{2}$ and epoxides with cobalt (II)/onium salt based catalysts. Appl. Catal. A Gen. 2009, 365, 194-198. [CrossRef]

43. Du, Y.; Cai, F.; Kong, D.I.; He, I.N. Organic solvent-free process for the synthesis of propylene carbonate from supercritical carbon dioxide and propylene oxide catalyzed by insoluble ion exchange resins. Green Chem. 2005, 7, 518-523. [CrossRef]

44. Ulusoy, M.; Cetinkaya, E.; Cetinkaya, B. Conversion of carbon dioxide to cyclic carbonates using diimine Ru (II) complexes as catalysts. Appl. Organomet. Chem. 2009, 23, 68-74. [CrossRef]

45. Kawanami, H.; Ikushima, Y. Chemical fixation of carbon dioxide to styrene carbonate under supercritical conditions with DMF in the absence of any additional catalysts. Chem. Commun. 2000. [CrossRef]

46. Jiang, J.-L.; Hua, R. Efficient DMF Catalyzed Coupling of Epoxides with $\mathrm{CO}_{2}$ under Solvent Free Conditions to Afford Cyclic Carbonates. Synth. Commun. 2006, 36, 3141-3148. [CrossRef]

47. Jing, $\mathrm{H}$; $\mathrm{Nguyen,} \mathrm{S.T.} \mathrm{SnCl}_{4}$-organic base: Highly efficient catalyst system for coupling reaction of $\mathrm{CO}_{2}$ and epoxides. J. Mol. Catal. A Chem. 2007, 261, 12-15. [CrossRef]

48. Wang, Y.; Sun, J.; Xiang, D.; Wang, L.; Sun, J.; Xiao, F.-S. A Facile, Direct Synthesis of Styrene Carbonate from Styrene and CO 2 Catalyzed by $\mathrm{Au} / \mathrm{Fe}(\mathrm{OH})_{3}-\mathrm{ZnBr}_{2} / \mathrm{Bu}_{4} \mathrm{NBr}$ System. Catal. Lett. 2009, 129, 437-443. [CrossRef]

49. Xie, Y.; Zhang, Z.; Jiang, T.; He, J.; Han, B.; Wu, T.; Ding, $\mathrm{K} . ~^{\mathrm{CO}_{2}}$ Cycloaddition Reactions Catalyzed by an Ionic Liquid Grafted onto a Highly Cross-Linked Polymer Matrix. Angew. Chem. 2007, 119, 7393-7396. [CrossRef]

50. He, L.-N.; Wang, J.-Q.; Wang, J.-L. Carbon dioxide chemistry: Examples and challenges in chemical utilization of carbon dioxide. Pure Appl. Chem. 2009, 81, 2069-2080. [CrossRef]

51. Liang, S.; Liu, H.; Jiang, T.; Song, J.; Yang, G.; Han, B. Highly efficient synthesis of cyclic carbonates from $\mathrm{CO}_{2}$ and epoxides over Cellulose/KI. Chem. Commun. 2011, 47, 2131.

52. Xiang, D.; Liu, X.; Sun, J.; Xiao, F.-S.; Sun, J. A novel route for synthesis of styrene carbonate using styrene and $\mathrm{CO}_{2}$ as substrates over basic resin R201 supported Au catalyst. Catal. Today 2009, 148, 383-388. [CrossRef]

53. Jutz, F.; Andanson, J.-M.; Baiker, A. Ionic Liquids and Dense Carbon Dioxide: A Beneficial Biphasic System for Catalysis. Chem. Rev. 2010, 111, 322-353. [CrossRef] [PubMed]

54. Yang, Z.-Z.; Zhao, Y.-N.; He, L.-N. $\mathrm{CO}_{2}$ chemistry: Task-specific ionic liquids for $\mathrm{CO}_{2}$ capture/activation and subsequent conversion. RSC Adv. 2011, 1, 545-567. [CrossRef]

55. Cheng, W.; Xiao, B.; Sun, J.; Dong, K.; Zhang, P.; Zhang, S.; Ng, F.T.T. Effect of hydrogen bond of hydroxyl-functionalized ammonium ionic liquids on cycloaddition of $\mathrm{CO}_{2}$. Tetrahedron Lett. 2015, 56, 1416-1419. [CrossRef]

56. Guglielmero, L.; Mezzetta, A.; Pomelli, C.S.; Chiappe, C.; Guazzelli, L. Evaluation of the effect of the dicationic ionic liquid structure on the cycloaddition of $\mathrm{CO}_{2}$ to epoxides. J. $\mathrm{CO}_{2}$ Util. 2019, 34, 437-445. [CrossRef]

57. Ji, L.; Luo, Z.; Zhang, Y.; Wang, R.; Ji, Y.; Xia, F.; Gao, G. Imidazolium ionic liquids/organic bases: Efficient intermolecular synergistic catalysts for the cycloaddition of $\mathrm{CO}_{2}$ and epoxides under atmospheric pressure. Mol. Catal. 2018, 446, 124-130. [CrossRef]

58. Liu, D.; Li, G.; Liu, H. Functionalized MIL-101 with imidazolium-based ionic liquids for the cycloaddition of $\mathrm{CO}_{2}$ and epoxides under mild condition. Appl. Surf. Sci. 2018, 428, 218-225. [CrossRef]

59. Liu, M.; Liang, L.; Liang, T.; Lin, X.; Shi, L.; Wang, F.; Sun, J. Cycloaddition of $\mathrm{CO}_{2}$ and epoxides catalyzed by dicationic ionic liquids mediated metal halide: Influence of the dication on catalytic activity. J. Mol. Catal. A Chem. 2015, 408, 242-249. [CrossRef]

60. Liu, M.; Zhao, P.; Gu, Y.; Ping, R.; Gao, J.; Liu, F. Squaramide functionalized ionic liquids with well-designed structures: Highly-active and recyclable catalyst platform for promoting cycloaddition of $\mathrm{CO}_{2}$ to epoxides. J. CO 2 Util. 2020, 37, 39-44. [CrossRef]

61. Mao, P.; Dai, W.; Yang, W.; Luo, S.; Zhang, Y.; Mao, J.; Luo, X.; Zou, J. Polymer nanoparticles grafted zinc-containing ionic liquids: A highly efficient and recyclable catalyst for cooperative cycloaddition of $\mathrm{CO}_{2}$ with epoxides. J. $\mathrm{CO}_{2}$ Util. 2018, 28, 96-106. [CrossRef]

62. Muniandy, L.; Adam, F.; Rahman, N.R.A.; Ng, E.-P. Highly selective synthesis of cyclic carbonates via solvent free cycloaddition of $\mathrm{CO}_{2}$ and epoxides using ionic liquid grafted on rice husk derived MCM-41. Inorg. Chem. Commun. 2019, 104, 1-7. [CrossRef]

63. Shang, Y.; Gong, Q.; Zheng, M.; Zhang, H.; Zhou, X. An efficient morpholinium ionic liquid based catalyst system for cycloaddition of $\mathrm{CO}_{2}$ and epoxides under mild conditions. J. Mol. Liq. 2019, 283, 235-241. [CrossRef]

64. Tharun, J.; Kathalikkattil, A.C.; Roshan, R.; Kang, D.-H.; Woo, H.-C.; Park, D.-W. Microwave-assisted, rapid cycloaddition of allyl glycidyl ether and $\mathrm{CO}_{2}$ by employing pyridinium-based ionic liquid catalysts. Catal. Commun. 2014, 54, 31-34. [CrossRef]

65. Wang, T.; Zheng, D.; Ma, Y.; Guo, J.; He, Z.; Ma, B.; Liu, L.; Ren, T.; Wang, L.; Zhang, J. Benzyl substituted imidazolium ionic liquids as efficient solvent-free catalysts for the cycloaddition of $\mathrm{CO}_{2}$ with epoxides: Experimental and Theoretic study. J. $\mathrm{CO}_{2}$ Util. 2017, 22, 44-52. [CrossRef]

66. Wang, T.; Zhu, X.; Mao, L.; Liu, Y.; Ren, T.; Wang, L.; Zhang, J. Synergistic cooperation of bi-active hydrogen atoms in protic carboxyl imidazolium ionic liquids to push cycloaddition of $\mathrm{CO}_{2}$ under benign conditions. J. Mol. Liq. 2019, 296, 111936. [CrossRef]

67. Wu, X.; Wang, M.; Xie, Y.; Chen, C.; Li, K.; Yuan, M.; Zhao, X.; Hou, Z. Carboxymethyl cellulose supported ionic liquid as a heterogeneous catalyst for the cycloaddition of $\mathrm{CO}_{2}$ to cyclic carbonate. Appl. Catal. A Gen. 2016, 519, 146-154. [CrossRef] 
68. Yang, C.; Liu, M.; Zhang, J.; Wang, X.; Jiang, Y.; Sun, J. Facile synthesis of DBU-based ionic liquids cooperated with ZnI 2 as catalysts for efficient cycloaddition of $\mathrm{CO}_{2}$ to epoxides under mild and solvent-free conditions. Mol. Catal. 2018, 450, 39-45. [CrossRef]

69. Zhang, Y.; Tan, Z.; Liu, B.; Mao, D.; Xiong, C. Coconut shell activated carbon tethered ionic liquids for continuous cycloaddition of $\mathrm{CO}_{2}$ to epichlorohydrin in packed bed reactor. Catal. Commun. 2015, 68, 73-76. [CrossRef]

70. Zheng, D.; Wang, L.; Jiang, J.; Liu, F.; Zhang, J. Effect of cluster of protic pyrazolium ionic liquids or epoxides on the cycloaddition of $\mathrm{CO}_{2}$. J. Mol. Liq. 2019, 295, 111652. [CrossRef]

71. Zhu, J.; Wang, S.; Gu, Y.; Xue, B.; Li, Y. A new and efficient method of graphene oxide immobilized with ionic liquids: Promoted catalytic activity for $\mathrm{CO}_{2}$ cycloaddition. Mater. Chem. Phys. 2018, 208, 68-76. [CrossRef]

72. Bhanage, B.M.; Fujita, S.-i.; Ikushima, Y.; Arai, M. Synthesis of dimethyl carbonate and glycols from carbon dioxide, epoxides, and methanol using heterogeneous basic metal oxide catalysts with high activity and selectivity. Appl. Catal. A Gen. 2001, 219, 259-266. [CrossRef]

73. Yano, T.; Matsui, H.; Koike, T.; Ishiguro, H.; Fujihara, H.; Yoshihara, M.; Maeshima, T. Magnesium oxide-catalysed reaction of carbon dioxide with an epoxide with retention of stereochemistry. Chem. Commun. 1997, 1129-1130. [CrossRef]

74. Yamaguchi, K.; Ebitani, K.; Yoshida, T.; Yoshida, H.; Kaneda, K. Mg-Al Mixed Oxides as Highly Active Acid-Base Catalysts for Cycloaddition of Carbon Dioxide to Epoxides. J. Am. Chem. Soc. 1999, 121, 4526-4527. [CrossRef]

75. Srivastava, R.; Srinivas, D.; Ratnasamy, P. Sites for $\mathrm{CO}_{2}$ activation over amine-functionalized mesoporous Ti(Al)-SBA-15 catalysts Microporous Mesoporous Mater. 2006, 90, 314-326. [CrossRef]

76. Lu, X.-B.; Wang, H.; He, R. Aluminum phthalocyanine complex covalently bonded to MCM-41 silica as heterogeneous catalyst for the synthesis of cyclic carbonates. J. Mol. Catal. A Chem. 2002, 186, 33-42. [CrossRef]

77. Srivastava, R.; Srinivas, D.; Ratnasamy, P. Syntheses of polycarbonate and polyurethane precursors utilizing $\mathrm{CO}_{2}$ over highly effcient, solid as-synthesized MCM-41 catalyst. Tetrahedron Lett. 2006, 47, 4213-4217. [CrossRef]

78. Qiao, K.; Ono, F.; Bao, Q.; Tomida, D.; Yokoyama, C. Efficient synthesis of styrene carbonate from $\mathrm{CO}_{2}$ and styrene oxide using zinc catalysts immobilized on soluble imidazolium-styrene copolymers. J. Mol. Catal. A Chem. 2009, 303, 30-34. [CrossRef]

79. Jing, H.; Tao, C.; Lili, J.; Mei, W.; Wenyuan, Q. Ruthenium Salen/phenyltrimethylammonium tribromide catalyzed coupling reaction of carbon dioxide and epoxides. Catal. Commun. 2007, 8, 1630-1634. [CrossRef]

80. Dai, W.-L.; Chen, L.; Yin, S.-F.; Luo, S.-L.; Au, C.-T. 3-(2-Hydroxyl-Ethyl)-1-Propylimidazolium Bromide Immobilized on SBA-15 as Efficient Catalyst for the Synthesis of Cyclic Carbonates via the Coupling of Carbon Dioxide with Epoxides. Catal. Lett. 2010, 135, 295-304. [CrossRef]

81. Jagtap, S.; Bhanushali, M.; Panda, A.; Bhanage, B. Synthesis of cyclic carbonates from carbon dioxide and epoxides using alkali metal halide supported liquid phase catalyst. Catal. Lett. 2006, 112, 51-55. [CrossRef]

82. Paddock, R.L.; Hiyama, Y.; McKay, J.M.; Nguyen, S.T. Co (III) porphyrin/DMAP: An efficient catalyst system for the synthesis of cyclic carbonates from $\mathrm{CO}_{2}$ and epoxides. Tetrahedron Lett. 2004, 45, 2023-2026. [CrossRef]

83. Bai, D.; Wang, Q.; Song, Y.; Li, B.; Jing, H. Synthesis of cyclic carbonate from epoxide and $\mathrm{CO}_{2}$ catalyzed by magnetic nanoparticlesupported porphyrin. Catal. Commun. 2011, 12, 684-688. [CrossRef]

84. Bai, D.; Wang, X.; Song, Y.; Li, B.; Zhang, L.; Yan, P.; Jing, H. Bifunctional Metalloporphyrins-Catalyzed Coupling Reaction of Epoxides and $\mathrm{CO}_{2}$ to Cyclic Carbonates. Chin. J. Catal. 2010, 31, 176-180.

85. Jin, L.; Jing, H.; Chang, T.; Bu, X.; Wang, L.; Liu, Z. Metal porphyrin/phenyltrimethylammonium tribromide: High efficient catalysts for coupling reaction of $\mathrm{CO}_{2}$ and epoxides. J. Mol. Catal. A Chem. 2007, 261, 262-266. [CrossRef]

86. Srivastava, R.; Srinivas, D.; Ratnasamy, P. Zeolite-based organic-inorganic hybrid catalysts for phosgene-free and solvent-free synthesis of cyclic carbonates and carbamates at mild conditions utilizing $\mathrm{CO}_{2}$. Appl. Catal. A Gen. 289 2005, 289, 128-134. [CrossRef]

87. Jing-Xian, C.; Bi, J.; Wei-Li, D.; Sen-Lin, D.; Liu-Ren, C.; Zong-Jie, C.; Sheng-Lian, L.; Xu-Biao, L.; Xin-Man, T.; Chak-Tong, A. Catalytic fixation of $\mathrm{CO}_{2}$ to cyclic carbonates over biopolymer chitosan-grafted quarternary phosphonium ionic liquid as a recylable catalyst. Appl. Catal. A Gen. 2014, 484, 26-32. [CrossRef]

88. Wei-Li, D.; Bi, J.; Sheng-Lian, L.; Xu-Biao, L.; Xin-Man, T.; Chak-Tong, A. Functionalized phosphonium-based ionic liquids as efficient catalysts for the synthesis of cyclic carbonate from expoxides and carbon dioxide. Appl. Catal. A Gen. 2014, 470, 183-188. [CrossRef]

89. Yang, Z.; Sun, J.; Liu, X.; Su, Q.; Liu, Y.; Li, Q.; Zhang, S. Nano-sized polydopamine-based biomimetic catalyst for the efficient synthesis of cyclic carbonates. Tetrahedron Lett. 2014, 55, 3239-3243. [CrossRef]

90. Wei-Li, D.; Bi, J.; Sheng-Lian, L.; Xu-Biao, L.; Xin-Man, T.; Chak-Tong, A. Polymer grafted with asymmetrical dication ionic liquid as efficient and reusable catalysts for the synthesis of cyclic carbonates from $\mathrm{CO}_{2}$ and expoxides. Catal. Today 2014, 233, 92-99. [CrossRef]

91. Cheng, W.; Chen, X.; Sun, J.; Wang, J.; Zhang, S. SBA-15 supported triazolium-based ionic liquids as highly efficient and recyclable catalysts for fixation of $\mathrm{CO}_{2}$ with epoxides. Catal. Today 2013, 200, 117-124. [CrossRef]

92. Sankar, M.; Ajithkumar, T.G.; Sankar, G.; Manikandan, P. Supported imidazole as heterogeneous catalyst for the synthesis of cyclic carbonates from epoxides and $\mathrm{CO}_{2}$. Catal. Commun. 2015, 59, 201-205. [CrossRef]

93. Xie, Y.; Yang, R.-X.; Huang, N.-Y.; Luo, H.-J.; Deng, W.-Q. Efficient fixation of $\mathrm{CO}_{2}$ at mild conditions by a Cr-conjugated microporous polymer. J. Energy Chem. 2014, 23, 22-28. [CrossRef] 
94. Song, B.; Guo, L.; Zhang, R.; Zhao, X.; Gan, H.; Chen, C.; Chen, J.; Zhu, W.; Hou, Z. The polymeric quaternary ammonium salt supported on silica gel as catalyst for the efficient synthesis of cyclic carbonate. J. $\mathrm{CO}_{2}$ Util. 2014, 6, 62-68. [CrossRef]

95. Motokura, K.; Itagaki, S.; Iwasawa, Y.; Miyaji, A.; Baba, T. Zinc-Accelerated Cycloaddition of Carbon Dioxide to Styrene Oxide Catalyzed by Pyrrolidinopyridinium Iodides. Top. Catal. 2014, 57, 953-959. [CrossRef]

96. Baj, S.; Krawczyk, T.; Jasiak, K.; Siewniak, A.; Pawlyta, M. Catalytic coupling of epoxides and $\mathrm{CO}_{2}$ to cyclic carbonates by carbon nanotube-supported quaternary ammonium salts. Appl. Catal. A Gen. 2014, 488, 96-102. [CrossRef]

97. Dai, W.-L.; Jin, B.; Luo, S.-L.; Yin, S.-F.; Luo, X.-B.; Au, C.-T. Cross-linked polymer grafted with functionalized ionic liquid as reusable and efficient catalyst for the cycloaddition of carbon dioxide to epoxides. J. $\mathrm{CO}_{2}$ Util. 2013, 3-4, 7-13. [CrossRef]

98. Lee, S.-D.; Kim, B.-M.; Kim, D.-W.; Kim, M.-I.; Roshan, K.R.; Kim, M.-K.; Won, Y.-S.; Park, D.-W. Synthesis of cyclic carbonate from carbon dioxide and epoxides with polystyrene-supported quaternized ammonium salt catalysts. Appl. Catal. A Gen. 2014, 486, 69-76. [CrossRef]

99. Siewniak, A.; Jasiak, K.; Baj, S. An efficient method for the synthesis of cyclic carbonates from $\mathrm{CO}_{2}$ and epoxides using an effective two-component catalyst system: Polymer-supported quaternary onium salts and aqueous solutions of metal salts. Appl. Catal. A Gen. 2014, 482, 266-274. [CrossRef]

100. Zhong, S.; Liang, L.; Liu, B.; Sun, J. ZnBr2/DMF as simple and highly active Lewis acid-base catalysts for the cycloaddition of $\mathrm{CO}_{2}$ to propylene oxide. J. $\mathrm{CO}_{2}$ Util. 2014, 6, 75-79. [CrossRef]

101. Bu, Z.; Qin, G.; Cao, S. A ruthenium complex exhibiting high catalytic efficiency for the formation of propylene carbonate from carbon dioxide. J. Mol. Catal. A Chem. 2007, 277, 35-39. [CrossRef]

102. Ramalingam, R.J.; Appaturi, J.N.; Pulingam, T.; Ibrahim, S.N.; Al-Lohedan, H.A. Synthesis, characterization and catalytic activity of ionic liquid mimic halides modified MCM-41 for solvent free synthesis of phenyl glycidyl carbonate. Mater. Chem. Phys. 2019, 233, 79-88. [CrossRef] 